nature is a physical land classification system which lends itself to interpretation for use-capability. This committee then has a major responsibility in the vital field of land management.

I am aware that land management falls within the jurisdictional field of the provinces and it may well be that not all of the provinces feel the need of undertaking a program of wildland classification at this stage. This is inevitable in a country of such varying conditions. However, as a national research organization, the Department of Forestry has a responsibility to encourage proper land use and to provide the technical assistance necessary to achieve it. The Department has recognized this responsibility, and, during the past year has recruited eight additional professionals and eight additional technicians to work in the field of forest land classification. During 1966-67 we shall be recruiting some eighteen additional professionals to work in the field of forest soils and forest land classification research. Thus, we are now prepared to work jointly or co-operatively with any province which is interested in developing the techniques for, and initiating, a land inventory in its forested zones.

Any contemplated program of wild land inventory should be planned with a full awareness of current land and soils research and of the availabiltiy of trained personnel. This Committee will therefore perform a useful function in examining the status of forest soils research in Canada and the facilities and prospects for ensuring a supply of trained "conservationists" for wild land management.

It may well be that the Department is overlooking possibilities in which we should become involved. Thus, we are very interested in the recommendations which will come out of this Committee and its sub-committees. I would like to assure you that the Department of Forestry will consider your recommendations very carefully and will treat them with the seriousness which you rightly expect.

May I take this opportunity to congratulate you on the establishment of this excellent Committee, and to wish you the best of luck at this, your initial meeting.

\title{
COMMENTS ON CANADA LAND INVENTORY
}

The inventory has been described in this issue by R. J. McCormack as Coordinator of the Forestry Sector. Mr. McCormack served as Chairman of the Forest Land Committee described in the Dec. 1965 issue of the Forestry Chronicle and mentioned above. The land capability study started in 1963 under ARDA will continue until 1969 and will cost an estimated $\$ 18,000,000$. To date, from 15 to 20 thousand of some 100 thousand square miles have been mapped.

Lack of trained personnel, the need for further education, the possibility of extending the program to all forest lands, need to further define objectives of the Canadian Land Inventory, and need for supporting research in forest mensuration, soils, and ecology were discussed by the Committee on Forest Land. Papers by Lacate on land inventory methods and by Hills on philosophy of physiographic site mapping are scheduled to appear in the June issue of the Chronicle. Expansion of studies of socio-economic aspects 
of land capability are planned. Four sub-committees were appointed. Education was chaired by Dean Ker; Research by Prof. Armson; Forest, Wildland and Watershed Land Inventory was chaired by Mr. Lacate; Dr. Bernier was appointed chairman of a committee on organic soils and horizons.

The Committee accepted a very broad definition of its responsibilities and interests in forest land. It agreed that classification for multiple use was feasible and that it was highly desirable to maintain and extend liaison with all groups having an interest in forest land. Although the meeting demonstrated the difficulty of achieving a Canadian point of view, its deliberations were very worthwhile. It is encouraging to report substantial progress by the Provinces in inventory of forest land of concern in the ARDA program.

J. H. G. SMITH

\section{Robert Coats St. Clair}

B.C. lost one of its senior foresters when Bob St. Clair passed away on January 12, 1966.

He was born in New Pierre, South Dakota, August 18, 1886 and graduated from the University of Idaho with the degree B.S. (C.E.) and later obtained his M.S.F. from the University of Michigan.

After completing his post-graduate work, he came north to work on railroad engineering with the C.P.R. in the Crows Nest Pass area. Later he joined the Dominion Forest Service and worked out of the Calgary office. From here he was induced, in 1920, to join the young B.C. Forest Service in the Vancouver District office.

Bob progressed rapidly in the Service to become District Forester, Vancouver Forest District and later held other D.F. appointments culminating in assignment in 1946 to Victoria Headquarters as Assistant Chief Forester from which position he retired in 1951 .

In 1952 he joined T. H. Wilkinson to form R. C. St. Clair \& Associates, a forestry consulting business in Vancouver.

$\mathrm{He}$ belonged to the Association of B.C. Foresters (B.C.R.F. No. 10, Life Member No. 8) and the Society of American Foresters as well as the C.I.F., in which he was an early Chairman and Director of the Vancouver Section. He always took an active part in professional affairs.

Bob died in his home at North Vancouver leaving his wife Eva, daughters Maggie and Betty, son Dick and 5 grandchildren.

His friendly manner, constructive comment, and above all his enthusiasm for forestry made him a popular member of the forestry fraternity. He will be missed.

M. W. GORMELX 